\title{
LINGUAGENS GRUPO DE ESTUDO E PESQUISA "PRÁTICAS DE indice ENSINO DE PORTUGUÊS"
}

\author{
Graziela Lucci de Angelo
}

O presente artigo tem por objetivo dar informações sobre o Grupo de Estudo e Pesquisa "Práticas de Ensino de Português" com relação ao seu funcionamento, objetivos, linha orientadora e metodologia de trabalho.

O Grupo, composto por aproximadamente dez professores de Língua Portuguesa do Ensino Fundamental da rede pública e particular da cidade de Santa Maria, reúne-se, quinzenalmente, no Centro de Artes e Letras da Universidade Federal de Santa Maria, na sala 1319 B, sob a coordenação de Graziela Lucci de Angelo, professora do Curso de Letras da UFSM.

O Grupo tem como objetivo geral discutir a prática pedagógica de Língua Portuguesa, buscando encontrar formas de garantir a aprendizagem efetiva da leitura e da escrita. Tem como objetivos específicos reorientar o ensino de Língua Portuguesa para o uso da língua em situações de efetiva interação verbal, adequar a prática pedagógica às necessidades dos alunos, priorizando suas dificuldades, explorar conteúdos gramaticais em função do uso da língua padrão, ler e discutir documentos oficiais voltados à reestruturação curricular do ensino de Língua Portuguesa, e participar do Seminário Novas Propostas divulgando trabalhos já elaborados pelos participantes do grupo através da apresentação de comunicações e pôsteres.

A proposta de trabalhar com os professores de Língua Portuguesa se justifica pela necessidade de qualificar continuamente esses profissionais, dada a formação geralmente frágil recebida nos cursos de licenciatura em Letras e a falta de espaço nas instituições de ensino (fundamental e médio) para um aperfeiçoamento profissional que permita aos professores conhecer e discutir os avanços já feitos nos estudos lingüísticos em relação ao ensino da Língua Portuguesa.

O Grupo de Estudo e Pesquisa "Práticas de Ensino de Português" se apóia teoricamente nas idéias propostas por FRANCHI (1988), GERALDI (1996) e POSSENTI (1997), que defendem que o ensino de língua materna deve se dar através de seu uso efetivo. Tais autores criticam o atual ensino pelo fato de a maior parte do tempo gasto no processo escolar ser destinado ao ensino da metalinguagem de análise da língua e não ao ensino da língua em si.

Tal posicionamento teórico pressupõe três concepções que são contribuições essenciais da Lingüística ao ensino de língua materna. 
São elas: concepções de linguagem, de língua e de texto.

A linguagem é concebida não como uma atividade escolar, mas como uma atividade constitutiva que se realiza na interação verbal. É uma atividade humana, histórica e social. A língua é entendida como o resultado de um processo coletivo, de um trabalho construtivo que se realiza nas interações verbais : é o sistema lingüístico e comunicativo de uma comunidade, um conjunto aberto de recursos expressivos, sempre em modificação porque é histórico. Conceber língua dessa forma significa entendê-la como uma realidade heterogênea, multifacetada, mutável, ou seja, um conjunto de variedades lingüísticas que se equivalem mas que se diferenciam pelo maior ou menor grau de prestígio social dado a elas. O texto é concebido como o produto concreto de um processo interlocutivo; é todo trecho falado ou escrito, independentemente de sua extensão, que constitui um todo coerente e unificado numa situação discursiva.

Tomando como base tais pressupostos, o centro do ensino passa a ser o texto, a língua em uso . O ensino, dessa forma, deixa de investir , como acontece no ensino tradicional de língua portuguesa, no conhecimento da descrição da língua para investir no aumento das possibilidades de uso adequado da língua. O equívoco do ensino tradicional de língua portuguesa está justamente na idéia de que o conhecimento gramatical pode melhor e garantir o desempenho lingüístico dos alunos. A experiência em sala de aula tem mostrado, há muito tempo , que o conhecimento gramatical não é, em seu todo , imprescindível para que os alunos possam aprender a ler criticamente e a escrever adequadamente.

Segundo os autores já citados, o ensino da língua materna deve se dar através de diferentes níveis de atividades: lingüísticas, epilingüísticas e metalingüísticas. Num primeiro momento, para que a aprendizagem seja mais produtiva, propõem o desenvolvimento dos dois primeiros níveis de atividades (lingüísticas e epilingüísticas)e , posteriormente, o das atividades metalingüísticas. Num primeiro estágio de ensino, desaparecem, dessa forma, a denominação, a classificação e a sistematização de fatos lingüísticos à luz de uma teoria gramatical, procedimentos tão comuns nos livros didáticos e no ensino tradicional. São propostas, ao invés disso, atividades de uso real da língua (atividades lingüísticas), que pressupõem o diálogo, a conversa, a interação entre interlocutores reais (professor e aluno ou aluno e aluno). Além disso, atividades que levem os alunos a operar e refletir sobre a própria linguagem (atividades epilingüísticas) podem se efetuar, por exemplo, comparando expressões, orações ,textos, transformando-os em outras possíveis alternativas que a própria língua oferece, experimentando modos de construção diferentes à disposição do falante. Só depois que o aluno tiver um bom domínio do uso da língua, são propostas atividades que o levem a falar sobre a linguagem e pesquisá-la como objeto de estudo e descrição, 
utilizando uma linguagem técnica (metalinguagem). São as atividades metalingüísticas. Nos primeiros anos de escolaridade, segundo essa proposta, o que se espera é o predomínio das atividades lingüística e epilingüística concretizadas na produção e interpretação de textos. Nos níveis mais altos de escolaridade, as atividades metalingüísticas terão seu lugar mas só após um longo e rico trabalho de uso e de reflexão sobre a linguagem.

Colocada a linha teórica que orienta o GEP "Práticas de Ensino de Português", resta esclarecer a metodologia de trabalho utilizada. O Grupo tem encontros periódicos quinzenais onde os participantes lêem e discutem tanto textos teóricos voltados para a linha orientadora do grupo como textos oficiais voltados à reestruturação do ensino de Língua Portuguesa; apresentam e colocam em discussão atividades voltadas ao ensino da oralidade, leitura e escrita que são previamente elaboradas em grupo e que devem estar sintonizadas com as posições teóricas assumidas pelo grupo de professores. No final de cada semestre é feita uma avaliação de todo o trabalho desenvolvido e também um planejamento para o semestre seguinte, sempre calcado nas necessidades encontradas pelos participantes do grupo.

O tipo de trabalho que está sendo desenvolvido pelo GEP " Práticas de Ensino de Português" está sintonizado com a tendência atual de substituir "cursos de treinamento" de professores por um trabalho em que Universidade e professores do ensino fundamental co-operem e construam, através de discussão conjunta, novas estratégias de ensino.

\section{BIBLIOGRAFIA}

FRANCHI, C. Criatividade e gramática . Secretaria da Educação. Coordenadoria de Estudos e Normas Pedagógicas. São Paulo, SE/CENP, 1988.

GERALDI, J. W. Linguagem e ensino: exercícios de militância e divulgação. Campinas, Mercado de Letras-ALB, 1996.

POSSENTI, S. Por que (não) ensinar gramática na escola. Campinas, Mercado Aberto-ALB, 1997.

[índice ] [ resumo ] 
